Neuroendocrinology 1991;54:I-VI

\title{
Contents, Vol. 54, 1991
}

Editor-in-Chief

S.M. McCann, Dallas, Tex.

\section{Associate Editors}

C.P. Fawcett, Dallas, Tex. L. Krulich, Dallas, Tex. J.C. Porter, Dallas, Tex.

Editorial Board

O.F.X. Almeida, München

N. Ben-Jonathan, Indianapolis, Ind.

D. Cardinali, Buenos Aires

K. Chihara, Kobe

G.V. Childs, Galveston, Tex.

W.F. Crowley, Boston, Mass.

M.F, Dallman, San Francisco, Calif.
A. Enjalbert, Paris
K. Fuxe, Stockholm
B.D. Goldman, Storrs, Conn.
A. Grossman, London
G.A. Gudelsky, Cleveland, Ohio
G.P. Kozlowski, Dallas, Tex.
S.W.J. Lamberts, Rotterdam
D. Lincoln, Edinburgh

R.M. MacLeod, Charlottesville, Va.

E. Mezey, Bethesda, Md.

E.E. Müller, Milano

S. Nakanishi, Kyoto

C. Oliver, Marseille

J.L. Roberts, New York, N.Y.

H.G. Spies, Beaverton, Oreg.

D.F. Swaab, Amsterdam

E. Terasawa, Madison, Wise.

F.J. Tilders, Amsterdam

M. Vigas, Bratislava

S.J. Watson, Ann Arbor, Mich.

J.O. Willoughby, Bedford Park

T.B. van Wimersma Greidanus, Utrecht

P.M. Wise, Baltimore, Md. 
KAHGER 
S. Karger $\cdot$ Medical and Scientific Publishers

Basel — München $\square$ Paris $\cdot$ London $\cdot$ New Y York $\cdot$ New Delhi $\cdot$ Bangkok $\square$ Singapore -Tokyo $\cdot$ Sydney

Drug Dosage

The authors and the publisher have exerted every effort to ensure that drug selection and dosage set forth in this text are in accord with current recommendations and practice at the time of publication. However, in view of ongoing research, changes in government regulations, and the constant flow of information relating to drug therapy and drug reactions, the reader is urged to check the package insert for each drug for any change in indications and dosage and for added warnings and precautions. This is particularly important when the recommended agent is a new and/or infrequently employed drug. 
All rights reserved.

No part of this publication may be translated into other languages, reproduced or utilized in any form or by any means, electronic or mechanical, including photocopying, recording, microcopying, or by any information storage and retrieval system, without permission in writing from the publisher or, in the case of photocopying, direct payment of a specified fee to the Copyright Clearance Center (see 'Information for Readers and Subscribers').

(c) Copyright 1991 by S. Karger AG, P.O. Box, CH- 4009 Basel (Switzerland) Printed in Switzerland on acid-free paper by Genossenschaftsdruckerei Zurich (gdz) 


\section{Contents Vol. 54,1991}

No. 1

\section{Original Paper}

Relative Contribution of Nervous System and Hormones to Hyperglycemia Induced by Thyrotropin-Releasing Hormone in Fed Rats Ishiguro, T.; Iguchi, A.; Kunoh, Y.; Goto, M.; Uemura, K.;

Miura, H.; Nonogaki, K.; Sakamoto, N.

Regulated Production and Secretion of Immunoreactive Neu ropeptide Y by Aggregating Fetal Brain Cells in Cultures Interaction of Estradiol, Alpha-Melanocyte-Stimulating the Female Rat Wilson, C.A.; Thody, A.J.; Hole, D.R.; Grierson, J.P.;

Celis, M.E

1 Barnea, A.; Hajibeigi, A.; Cho, G.; Magni, P

Role of Testosterone in the Regulation of Tuberoinfundibular

Toney, T.W.; Lookingland, K.J.; Moore, K.E.

Hormone, and Dopamine in the Regulation of Sexual Receptivity in

Influence of Diabetes on the Gonadotropin Response to the

Negative Feedback Effect of Testosterone and Hypotha-

lamic Neurotransmitter Turnover in Adult Male Rats

Chandrashekar, V.; Steger, R.W.; Bartke, A.; Fadden, C.T.;

Kienast, S.G

714

Subcellular Distribution of Corticotropin-Releasing-Fac-

tor-Like Immunoreactivity in Rat Central Nervous Sys

tem

Cain, S.T.; Owens, M.J.; Nemeroff, C.B

Effect of Head-Up Tilt on Vasopressin Secretion and Arterial

Pressure in Anesthetized Rats

Golin, R.M.A.; Keil, L.C.; Ganong, W.F .

Effects of Active Immunization against Gonadotropin-Releas-

ing Hormone on the Concentrations of Noradrenaline,

Dopamine, 5-Hydroxytryptamine and Some of Their Me

tabolites in the Brain and Sexual Organs of Male Rats

Juorio, A.V.; Li, X.M.; Gonzalez, A.; Chedrese, P.J.;

Murphy, B.D

23

Dopaminergic Neurons in the Male Rat

Effects of Daily Afternoon Melatonin Administration on

Monoamine Accumulation in Median Eminence and Stria-

turn of Ovariectomized Hamsters Receiving Pargyline

Alexiuk, N.A.; Vriend, J 55

Expression of Basic Fibroblast Growth Factor and Its Receptor in the Rat Subfornical Organ

Frautschy, S.A.; Gonzalez, A.M.; Martinez Murillo, R.;

Carceller, F.; Cuevas, P.; Baird, A

Indirect Action of Elevated Potassium and Neuropeptide Y on

$\alpha \mathrm{MSH}$ Secretion from the Pars Intermedia of Xenopus lae-

vis: A Biochemical and Morphological Study

Koning, H.P. de; Jenks, B.G.; Scheenen, W.J.J.M.; Rijk,

E.P.C.T. de; Caris, R.T.J.M.; Roubos, E.W 
Suckling-Induced Changes of Vasoactive Intestinal Peptide Concentrations in Hypothalamic Areas Implicated in the Control of Prolactin Release

Chiocchio, S.R.; Parisi, M.; de las Nieves; Vitale, M.L.;

Tramezzani, J.H

Cholinergic Modulation of Growth Hormone Secretion Induced by Galanin in Rats

Tanoh, T.; Shimatsu, A.; Murakami, Y.; Ishikawa, Y.;

Yanaihara, N.; Imura, H

\section{No. 2}

\section{Original Paper}

Amygdaloid Lesions: Differential Effect on Conditioned Stress and Immobilization-Induced Increases in Corticosterone and Renin Secretion

Van de Kar, L.D.; Piechowski, R.A.; Rittenhouse, P.A.;

Gray, T S

Delayed Puberty in the Male Djungarian Hamster: Effect of

Short Photoperiod or Melatonin Treatment on the GnRH

Neuronal System

Buchanan, K.L.; Yellon, S.M

Suprachiasmatic Nucleus Lesions Abolish Photoperiod-Induced Changes in the Testis Function and GnRH Immuno reactivity in the Mink, a Short-Day Breeder

Maurel, D.; Boissin-Agasse, L.; Roch, G.; Herbuté, S.;

Boissin, J.

Adrenalectomy and Experimental Hypercorticalism Modulate the Basal, Corticotropin-Releasing-Hormone- and Arginine-Vasopressin-Stimulated Release of Hypothalamic Beta-Endorphin

Patchev, V.K.; Racké, K.; Almeida, O.F.X.

Opioid-Receptor-Mediated Inhibition of $\left[{ }^{3} \mathrm{H}\right]$ Dopamine but Not $\left[{ }^{3} \mathrm{H}\right]$ Noradrenaline Release from Rat Mediobasal Hy-pothalamus Slices Heijna, M.H.; Padt, M.; Hogenboom, F.; Schoffelmeer,

A.N.M.; Mulder, A.H

A Sex-Specific Cytochrome P-450(F-1) Colocalized with Var ious Neuropeptides in the Paraventricular and Supraoptic Nuclei of Female Rats

Lin, L.-P.; Lee, Y.; Tohyama, M.; Shiosaka, S

Recovery of Pituitary-Gonadal Function in Male and Female Rats after Prolonged Administration of a Potent Antagonist of Luteinizing Hormone-Releasing Hormone (SB-75) Bokser, L.; Srkalovic, G,; Szepeshazi, K.; Serially, A.V. . 136

Is Reverse Triiodothyronine a Physiological Nonactive Com petitor for the Action of Triiodothyronine upon the Elec trical Properties of GH3 Cells?

duPont, J.S 
Release of Luteinizing Hormone-Releasing Hormone, ß-En-dorphin and Noradrenaline by the Nucleus Infundibu-laris/Median Eminence during Periovulatory Period in the Sheep

Domański, E.; Chomicka, L.K.; Ostrowska, A.; Gajewska,

A.; Mateusiak, K

Comparative Distribution of Immunoreactive Pituitary Ade-nylate Cyclase Activating Polypeptide and Vasoactive Intestinal Polypeptide in Rat Forebrain Köves, K.; Arimura, A.; Görcs, T.G.; Somogyváry-Vigh, A. 159

Possible Involvement of Endogenous Opioid Peptides in the

Inhibition of Arginine Vasopressin Release by $\gamma$-Amino-

butyric Acid in Conscious Rats

Otake, K.; Kondo, K.; Oiso, Y.

Pharmacologic Evidence that a D2 Receptor Subtype Me

diates Dopaminergic Stimulation of Prolactin Secretion

from the Anterior Pituitary Gland

Burris, T.P.; Stringer, L.C.; Freeman, M.E

Announcement

\section{No. 3}

\section{Original Paper}

Diethylstilbestrol- and Pregnancy-Induced Changes in Rat Neurointermediate Lobe Oxytocin, Arginine Vasopressin, Methionine Enkephalin and Dynorphin

Schriefer, J.A . 185

Sleep-Associated Augmentation and Synchronization of Luteinizing Hormone Pulses in Adult Men Fehm, H.L.; Clausing, J.; Kern, W.; Pietrowsky, R.; Born, J. 192

Demonstration of Insulin-Like Growth Factors I, II and Het erogeneous Insulin-Like Growth Factor Binding Proteins in the Cyst Fluid of Patients with Craniopharyngioma

Zumkeller, W.; Sääf, M.; Rähn, T.; Hall, K.

Influences of Norepinephrine, and Adrenergic Agonists and

Antagonists on Gonadotropin Secretion from Dispersed

Pituitary Cells of Goldfish, Carassius auratus

Chang, J.P.; Van Goor, F.; Acharya, S.

Gonadotropin Secretion during Aging in Postmenopausal Women Rossmanith, W.G.; Scherbaum, W.A.; Lauritzen, C. ... 211

Muscarinic Cholinergic Control of Vasopressin Secretion from

the Acute Hypothalamoneurohypophysial Explant

Michels, KM.; Meeker, R.B.; Hayward, J.N.

Effects of Tumor-Induced Hyperprolactinemia on LH Secre

tion following Stimulation of the Medial Preoptic Area,

Pituitary Responsiveness and the Estrogen-Induced LH

Surge

Shu, C; Selmanoff, M

Vasopressin mRNA Expression in Individual Magnocellular

Neuroendocrine Cells of the Supraoptic and Paraventricu-

lar Nucleus in Response to Water Deprivation

Meeker, R.B.; Greenwood, R.S.; Hayward, J.N.

Prolactin Stimulates Rat Hypothalamic Corticotropin-Releas-

ing Hormone and Pituitary Adrenocorticotropin Secretion

in vitro

Weber, R.F.A.; Calogero, A.E 
The Effect of Hypothalamo-Pituitary Disconnection on the Functional and Morphologic Development of the Pituitary-Adrenal Axis in the Fetal Sheep in the Last Third of Gestation

Antolovich, G.C.; McMillen, I.C.; Robinson, P.M.; Silver,

M.; Young, I.R.; Perry, R.A...

The Effect of Interleukin-6 on Pituitary Hormone Release in

vivo and in vitro

Lyson, K.; McCann, S.M

Bihormonal Cells Producing Gonadotropins and Prolactin in a

Rat Pituitary Tumor Cell Line (RC-4B/C)

Polkowska, J.; Bérault, A.; Hurbain-Kosmath, I.; Jolly, G.;

Jutisz, M.

Anterolateral Hypothalamic Deafferentation Inhibits Histamine-Induced Prolactin Secretion and Potentiates TRHInduced Thyrotropin Secretion in Male Rats

Tuominen, R.K.; Makara, G.B.; Männistö, P.T

Prolactin Short-Loop Feedback and Prolactin Inhibition of

Luteinizing Hormone Secretion during the Breeding Sea

son and Seasonal Anoestrus in the Ewe

Curlewis, J.D.; McNeilly, A.S .

Ovarian Role in the Modulation of Pituitary Responsiveness

to Growth Hormone-Releasing Hormone in Rats

Aguilar, E.; Pinilla, L

Arginine Reinstates the Somatotrope Responsiveness to Intermittent Growth Hormone-Releasing Hormone Administration in Normal Adults

Ghigo, E.; Arvat, E.; Valente, F.; Nicolosi, M.; Boffano,

G.M.; Procopio, M.; Bellone, J.; Maccario, M.; Mazza, E.;

Camanni, F

Hydrolysis of Atrial and Brain Natriuretic Peptides by the Human Astrocytoma Clone D384 and the Neuroblastoma Line SH-SY5Y dos Santos Medeiros, M.; Balmforth, A.J.; Vaughan,

P.F.T.; Turner, A.J 295

Arginine-Vasopressin in Anterior Pituitary Cells: In situ Hybridization of mRNA and Ultrastructural Localization of Immunoreactivity Terrier, C; Chabot, J.-G.; Pautrat, G.; Jeandel, L.; Gray,

D.; Lutz-Bucher, B.; Zingg, H.H.; Morel, G 303

Announcement

\section{No. 4}

\section{Original Paper}

Acute Inhibition of Pituitary LH Release in the Male Rat by the Glucocorticoid Agonist Decadron Phosphate

Briski, K.P.; Sylvester, P.W

Interactions between the Noradrenergic and Opioid Peptidergic Systems in Controlling the Electrical Activity of Lutein izing Hormone-Releasing Hormone Pulse Generator in Ovariectomized Rats

Nishihara, M.; Hiruma, H.; Kimura, F

Maintenance of LHRH and Oxytocin Neurons in Slice Explants Cultured in Serum-Free Media: Effects of Tetrodotoxin on Gene Expression

Wray, S.; Kusano, K.; Gainer, H. 


\section{Contents}


Influence of Hypothyroidism Duration on Developmental Changes in the Hypothalamic Factors Implicated in

Growth Hormone Secretion in the Male Rat

Varela, C; Cacicedo, L.; Fernandez, G.; de los Frailes, T.;

Sanchez Franco, F. 340

Anterograde Nerve Degeneration after Superior Cervical Gan-glionectomy Coexists with a Decrease in Arginine Vaso-pressin Release in Rats

Romeo, H.E.; Spinedi, E.; Esquifino, A.I.; Estivariz, F.;

Cardinali, D.P 346

Regulation of Hypothalamic Gonadotropin-Releasing Hor mone Secretion in Experimental Uremia: In vitro Studies

Wibullaksanakul, S.; Handelsman, D.J

Interaction of Carp Growth Hormone-Releasing Factor and

Somatostatin on in vitro Release of Growth Hormone in

Rainbow Trout (Oncorhynchus mykiss)

Luo, D.L.; McKeown, B.A

Estrogen Increases Spine Density in Ventromedial Hypotha

lamic Neurons of Peripubertal Rats

Segarra, A.C.; McEwen, B.S

Activin-A Modulates Gonadotropin-Releasing Hormone Secretion from a Gonadotropin-Releasing Hormone-Secreting Neuronal Cell Line

González-Manchón, C; Bilezikjian, L.M.; Corrigan, A.Z.;

Mellon, P.L.; Vale, W

Septal and Hippocampal Release of Vasopressin and Oxytocin

during Late Pregnancy and Parturition in the Rat

Landgraf, R.; Neumann, I.; Pittman, Q.J

Evaluation of the Sites of Opioid Influence on Anterior Pitu

itary Hormone Secretion Using a Quarternary Opiate An

tagonist

Simpkins, J.W.; Swager, D.; Millard, W.J

Stimulation of Hypothalamic Prolactin Release by Veratridine and Angiotensin II in the Female Rat: Effect of Ovariec-

tomy and Estradiol Administration

DeVito, W.J.; Stone, S.; Avakian, C

Forskolin-Associated Luteinizing Hormone Release by Rat

Anterior Pituitary Glands: Effects of Castration and Estra

diol Replacement

Kolp, L.A.; Krieg, R.J., Jr.; Evans, W.S

Modulation of the Effects of N-Methyl-A $\mathrm{A}_{i}$-Aspartate on $\mathrm{Lu}$

teinizing Hormone by the Ovarian Steroids in the Adult

Rhesus Monkey

Reyes, A.; Xia, L.; Ferin, M

Sleep-Related Growth Hormone Secretion in Human Obesity: Effect of Dietary Treatment

Ferini-Strambi, L.; Franceschi, M.; Cattaneo, A.G.;

Smirne, S.; Calori, G.; Caviezel, F

Ultrastructural Evidence of a Sexual Dimorphism in the Neu-

ropil of the Medial Preoptic Nucleus of the Rat: A Quanti

tative Study

Larriva-Sahd, J .

\section{Rapid Communication}

Insulin-Like Growth Factor I: A Possible Metabolic Signal

Involved in the Regulation of Female Puberty

Hiney, í K.; Ojeda, S.R.; Dees, W.L.

Announcements 


\section{Original Paper}

Regulation of Hypothalamic Gonadotropin-Releasing Hormone and Neuropeptide Y Concentrations by Progesterone and Corticosteroids in Immature Rats: Correlation with Luteinizing Hormone and Follicle-Stimulating Hormone Release Brann, D.W.; McDonald, J.K.; Putnam, CD.; Mahesh, V.B. 425

Effect of Medial Zona Incerta Lesions on the Ovulatory Surge of Gonadotrophins and Prolactin in the Rat Sanghera, M.K.; AnselmoFranci, J.; McCann, S.M. . . 433

Caffeine Enhances the Speed of the Recovery of the Hypothal-amo-Pituitary-Adrenocortical Axis after Chronic Predniso-lone Administration in the Rat

Marzouk, H.F.A.I.; Zuyderwijk, J.; Uitterlinden, P.; van

Koetsveld, P.; Blijd, J.J.; Abou-Hashim, E.M.; El-Kan-

nishy, M.H.; de Jong, F.H.; Lamberts, S.W.J....

Naltrexone Does Not Reverse the Inhibitory Effect of Chronic Restraint on Gonadotropin Secretion in the Intact Male Rat

González-Quijano, M.I.; Ariznavarreta, C; Martin, A.I.;

Tresguerres, J.A.F.; López-Calderón, A

Autoradiographic Analyses of the Effects of Restraint-Induced

Stress on 5-HT $\left.\right|_{\mathrm{A}}, 5-\mathrm{HT}_{\mathrm{lc}}$ and 5-HT $\mathrm{H}_{2}$ Receptors in the Dor

sal Hippocampus of Male and Female Rats

Mendelson, S.D.; McEwen, B.S.

Influence of Human Corticotropin-Releasing Hormone and

Adrenocorticotropin upon Spontaneous Growth Hormone

Secretion

Wiedemann, K.; von Bardeleben, U.; Holsboer, F....

Nerve Fibers in the Rat Posterior Pituitary Lobe Contain Pro-somatostatin (1 -64) Mikkelsen, J.D.; Bersani, M.; Hoist, J.J.; Larsen, P.J. . . 469

Effect of Cold Exposure on the Hypothalamic Release of Thy-

rotropin-Releasing Hormone and Catecholamines

Rondeel, J.M.M.; de Greef, W.J.; Hop, W.C.J.; Rowland,

D.L.; Visser, T.J. 477

Influence of Pentobarbital and Urethane on Release from

Magnocellular Neurons

Cheng, S.W.T.; North, W.G

Stimulation of Adrenocorticotropin but Not Prolactin and

Catecholamine Release by N-Methyl-Aspartic Acid

Jezová, D.; Oliver, C; Jurcovicová, J

Some Events of Thyrotropin-Releasing Hormone Metabolism

Are Regulated in Lactating and Cycling Rats

Uribe, R.M.; Joseph-Bravo, P.; Pasten, J.; Ponce, G.;

Méndez, M.; Covarrubias, L.; Charli, J.-L

Interferon-Alpha-2-Induced Stimulation of ACTH and Corti-

sol Secretion in Man

Müller, H.; Hammes, E.; Hiemke, C; Hess, G

Differential Development of Insulin-Like Growth Factor I

Binding in the Suprachiasmatic Nucleus and Median Emi

nence of the Rat Hypothalamus

Michels, K.M.; Saavedra, J.M.

Roles of Somatostatin and Growth Hormone-Releasing Factor in Ether Stress Inhibition of Growth Hormone Release Aguila, M.C.;

Pickle, R.L.; Yu, W.H.; McCann, S.M. ..515 
Effects of Acute and Prolonged Glucose Excess on Growth Hormone Release by Cultured Rat Anterior Pituitary

Cells

Renier, G.; Serri, 0

Electrophysiological Actions of Oxytocin on Hypothalamic Neurons in vitro: Neuropharmacological Characterization and Effects of Ovarian Steroids

Kow, L.-M; Johnson, A.E.; Ogawa, S.; Pfaff, D.W .526

Announcements .536

\section{No. 6}

\section{Original Paper}

Neurons in the Rat Arcuate Nucleus Are Hyperpolarized by GABAB and $\mu$-Opioid Receptor Agonists: Evidence for Convergence at a Ligand-Gated Potassium Conductance Loose, M.D.; Ronnekleiv, O.K.; Kelly, M.J.

Naloxone Increases the Release of Oxytocin, but Not Vaso-

pressin, within Limbic Brain Areas of Conscious Partu rient Rats: A Push-Pull Perfusion Study

Neumann, I.; Russell, J.A.; Wolff, B.; Landgraf, R 545

In vitro Effect of Thyroxine on Cholinergic Neurotransmission in Rat Sympathetic Superior Cervical Ganglion Landa, M.E.; Gonzalez Burgos, G; Cardinali, D.P. . . . 552

A Prepro-TRH Connecting Peptide (Prepro-TRH 160-169)

Potentiates TRH-Induced TSH Release from Rat Peri-

fused Pituitaries by Stimulating Dihydropyridine- and

Omega-Conotoxin-Sensitive $\mathrm{Ca}^{2+}$ Channels

Roussel, J.-P.; Hollande, F.; Bulant, M.; Astier, H

Attenuation of the Suckling-Induced Prolactin Release and the

High Afternoon Oscilliations of Plasma Prolactin Secre

tion of Lactating Rats by Antiserum to Vasopressin

Nagy, G.M.; Görcs, T.J.; Halász, B......

Estrogen Induces Ultrastructural Changes in Progesterone Re ceptor-Containing GABA Neurons of the Primate Hypothalamus

Leranth, C; Shanabrough, M.; Naftolin, F.

Influence of Gonadectomy and Testosterone Supplementation on the Postnatal Development of Vasopressin and Oxytocin-Containing Nucleus of the Pig Hypothalamus van Eerdenburg, F.J.C.M.; Lugard-Kok, C.M.J.E.; Dieleman, S.J.; Bevers, M.M.; Swaab, D.F . 
Endogenous Opioid Suppression of the Luteinizing Hormone

Pulse Frequency and Amplitude in the Ewe: Hypothalamic

Sites of Action

Whisnant, C.S.; Havern, R.L.; Goodman, R.L

Preproenkephalin A Gene Expression in Rat Pineal

Aloyo, V.J .594

Why Are Several Inhibitory Transmitters Present in the Inner-

vation of Pituitary Melanotrophs? Actions and Interac

tions of Dopamine, GABA and Neuropeptide Y on Secre

tion from Neurointermediate Lobes of Xenopus laevis

Kongsamut, S.; Shibuya, I.; Douglas, W.W

Growth Hormone and Somatostatin Gene Expression in Adult and Aging Rats as Measured by Quantitative in situ Hybridization

Martinoli, M.G.; Ouellet, J.; Rhéaume, E.; Pelletier, G. . 607

In vivo Effects of Serotonergic Agents on Alpha-Melanocyte-Stimulating Hormone Secretion

Carr, J.A.; Saland, L.C.; Samora, A.; Benavidez, S.; Kro-

bert, $\mathrm{K}$

Role of the Vasoactive Intestinal Peptide in a Neuroendocrine Regulation of the Adrenal Cortex

Ehrhart-Bornstein, M.; Bornstein, S.R.; Scherbaum, W.A.;

Pfeiffer, E.F.; Hoist, J.J .....

Serum Luteinizing Hormone, Prolactin, and Thyrotropin and Their Pituitary Subunit mRNA Levels during Proestrus in the Syrian Hamster

Howes, K.A.; Menendez-Pelaez, A.; Reiter, R.J.; Vaughan,

M.K.; Hensel, C.H.; Vaughan, G.M.

Altered Adrenocorticotropin, Corticosterone and Oxytocin Responses to Stress during Chronic Salt Load Chowdrey, H.S.; Jessop, D.S.;

Patel, H.; Lightman, S.L. . 635

Influence of 5-HT1 and 5-HT2 Receptor Antagonists on Insu

lin-Induced Adrenomedullary Catecholamine Release

Chaouloff, F.; Gunn, S.H.; Young, J.B

Involvement of Histamine in the Mediation of the Stress-Induced Release of Alpha-Melanocyte-Stimulating Hormone in Male Rats

Knigge, U.; Matzen, S.; Hannibal, T.; Jørgensen, H.; War-

berg, J.

5,7-Dihydroxytryptamine and Gonadal Steroid Manipulation

Alter Spine Density in Ventromedial Hypothalamic Neu

rons

Frankfurt, M.; McEwen, B.S

Announcements

Author Index

Subject Index 